\title{
Practical Teaching, Social Resources Embeddedness, and Undergraduate Employment
}

\author{
Lei Zhou*, Li Ma, Rui Wang \\ Accounting College \\ Wuhan Textile University \\ Wuhan, P. R. China \\ myjoan216@126.com
}

\begin{abstract}
This paper analyzes the social resources embedded in practical teaching and its impact on undergraduate employment, in order to provide guidance for solving the problem of "employment difficulties" caused by the disconnection between classroom teaching and enterprise needs. Firstly, social resources are divided into three categories: human resources, information resources and intellectual resources. Next, a questionnaire survey is conducted among undergraduates in Wuhan, focusing on the embedding of three types of social resources in the three practical teaching patterns as campus practical teaching, social practical teaching and graduation thes is teaching, and their impact on the employment of undergraduates. The results reveal that human resource with the highest degree of embeddedness in social practice and graduation thesis, has the greatest impact on undergraduates' employment, while intellectual resources with the highest degree of embeddedness in campus teaching practice, has the greatest impact on graduates' employment. Therefore, with varying practical teaching patterns, we should attach importance to the cultivation and maintenance of key social resources, so as to enhance its positive role in undergraduate employment.
\end{abstract}

Keywords-undergraduate employment; practical teaching; social resource embeddedness; human resource; information resource; intellectual resource

\section{INTRODUCTION}

Nowadays, employers request that undergraduates be equipped with not only certain professional theoretical knowledge, but also a strong ability of applying their knowledge and solving practical problem. Practical teaching is an independent teaching module to work with theoretical teaching. Through multiple teaching methods such as experimental teaching, practical training, graduation project, innovation ability training, social practice and so on, practical teaching, which centers on students, accomplishes the students' aim of comprehensive development of various abilities. In this process, students gradually understand their occupational direction and career position, learn relevant knowledge and skills, plan their own career, promote the accuracy and matching of the job employment. In a word, practical teaching is a critical means for undergraduates to get ready for jobhunting.

(Sponsors)Hubei Provincial Department of Education for Humanities and Social Sciences Research Project (No. 17Q095); 2017 Wuhan Textile University Teaching Research Project

\section{LITERATURES REVIEW}

\section{A. Related Studies on Social Resource Embedded}

The important role of social resource embedding has been extensively recognized in the related researches which mainly focus on business operations and strategic alliances. Social resource is the whole resources which is produced by, embedded in and used among social relations of enterprises [1]. The research shows that social resource will influence enterprise performance, with varying effect relating to enterprise scale, ownership type, and industry growth rate [2,3] Its response mechanism is presented as: by making use of internal and external social capital adequately, enterprises could urge the sharing and communication of knowledge, accelerate technological innovation, reduce business transaction costs, broaden corporate financing channels and strengthen the ability against to risk. As a result, they enhance enterprise competitive power, and affect corporate performance positively [4]. By further research, the kinds of social resource will affect corporate performance as well $[5,6]$. Collins and Clark found that there is a positive relation between social network and stock prices for new high-tech enterprises [7]. By a perspective of cluster enterprise growth, Wei and Gou studied the capacity growth and social resource embedded in CHINT Group [8]; Wu and Dai proved that corporate social networks have a positive effect on the development of SME clusters [9]; $\mathrm{Ma}$ and He found that the network relationship embedded in SMEs has a significant positive impact on their technological innovation performance [10]. By another perspective of organizational learning to observe the influence of social resource embedded on strategic alliance, it is found that the interactions between cooperation partners help enterprises with the abilities of designing and managing strategic alliances [11], consolidating corporate asset reserve and increase the rental of relationships [12].

\section{B. Related Studies on Practical Teaching}

Difficult employment for undergraduates has become a social problem of high concern, which results from the disconnection between classroom teaching and enterprise demand partly. To strengthen professional training and promote students' practical ability of analyzing and solving problems, domestic universities introduce school-enterprise cooperation model into practical teaching section $[13,14]$. The 
researches around this topic are divided into three categories: Firstly, the school-enterprise cooperated practical teaching design of specific courses and profession, for example accounting, e-commerce and computer mostly [15]. Secondly, varying practical teaching patterns has taken shape, such as graduation design and research cooperation, social practice, cooperation in the class $[16,17]$. Thirdly, the optimization of school-enterprise cooperation mechanism from teaching team building, teaching content selection and operation mechanism adjustment [18].

Current studies have made progress yet, there are some obvious defects. First, in terms of the subject, it is that vocational colleges launched, boosted and innovated related works, so it is doubtful to mimic such practices for practical teaching in undergraduate colleges. Second, in terms of the content, current studies did not discuss the relations between the practical teaching and undergraduates employment. Does the former have significant influence on the latter? How significantly it matters if exists? Both research defects reveal the vacancy of undergraduate universities in the employmentoriented researches of practical teaching. Therefore, not only university management personnel but also teachers should take practical teaching innovation and undergraduates employment seriously and urgently. The following sections analyze the social resources embedded in practical teaching, carry out a survey to reveal its impact on undergraduate employment.

\section{SOCIAL RESOURCES EMBEDDED IN PRACTICAL TEACHING}

Social resources exist as the form of intangible resources, Ma divides social resources into two categories: human resource and economic resources [19]. Both are divided into three categories in detail: human resource, information resources and intellectual resources. According to the categories, the following section analyzes the forms of human resource, information resources and intellectual resources in typical activities of practical teaching.

\section{A. Human Resource}

In this paper, human resources mainly refer to all interpersonal connections generated in the process of teacherpupil interaction and pupil-pupil interaction in the practical teaching. The concept is concert with the authoritative definition of social capital suggested by Nahapitet and Ghoshal They said that social capital is the resources developed from the history of members' interaction, and resources produced and utilized by any member, such as trust among members, standards and sanctions, identity and solidarity [20].

\section{B. Information Resource}

Ma believes that the information refers to signals or messages of certain things, it is worthwhile for such information provides foundation and give directions to human behavior [19]. In this paper, we define information resources as general term for all information in practical teaching that can be utilized for producing benefits.

\section{Intellectual Resource}

Intellectual resources can be further divided into scientific resources, knowledge resources and educational resources [19]. Scientific resources refer to resources existed in the form of science and technology, including all kinds of existed technology and potential technology which can produce social wealth. Development and utilization of knowledge resources is the main symbol of the degree of regional economic development and its value will be further enlarged in the era of knowledge-based economy. Educational resources are the basis for providing human resources for the society, as a bond to inherit scientific and technological resources. In this paper, intellectual resources refer to knowledge and technology development and utilization ability produced or acquired in practical teaching.

\section{SURVEY AND RESULT ANALYSIS}

A survey was carried out on full-time undergraduates in Wuhan Textile University by questionnaires and semistructured interviews to analyze the impact of social resource embedded in practical teaching on their employment. The questionnaire is designed as two parts. The first part consisting of six questions is about basic information, including gender, age, major, family background, participation in practical teaching activities, employment situation. The second part consisting of 18 questions. In this part, we asked (1) if graduates obtained three kinds of social resources in each practical teaching and (2) what kinds of social resources played an import role on their employment.

We issued 230 questionnaires and 218 questionnaires were recovered, of which 203 questionnaires were valid. Among the samples, $51.23 \%$ were male and $48.77 \%$ were female. The ages concentrated in 22 to 23 years old. Students majoring in account, financial management, engineering cost occupied 43.8\%, 28.1\% and 38.1\% respectively. Among interviewees $72.91 \%$ came from ordinary family, while $11.33 \%$ enjoyed a wealthier life and $10.34 \%$ had in difficult economic conditions. All the respondents participated in three types of practical teaching activities and $97.5 \%$ had signed employment contracts.

\section{A. The Influence of Social Resources Embedded in Campus Practice Teaching on Undergraduates Employment}

Campus Practical teaching refers to factory practice simulation in the study. In the process of practice, students gradually absorb knowledge and experience from teachers to accumulate their own intellectual resources; in the process of interaction, human resources and information resources contribute to enrich students' social functions; eventually, students are improved employment competitiveness from personal ability and social attribute.

In this part, we asked (1) if graduates obtained three kinds of social resources in campus practical teaching and (2) what kinds of social resources played an import role on their employment? Survey results are shown in TABLE I . 
TABLE I.

THE ACCESSIBILITY AND IMPORTANCE OF SOCIAL RESOURCES IN CAMPUS PRACTICE TEACHING

\begin{tabular}{|l|l|l|c|c|}
\hline \multicolumn{2}{|c|}{ practice teaching pattern } & \multicolumn{3}{c|}{ Social Resource } \\
\cline { 3 - 5 } & $\begin{array}{c}\text { Human } \\
\text { resource }\end{array}$ & $\begin{array}{l}\text { Information } \\
\text { resource }\end{array}$ & $\begin{array}{l}\text { Intellectual } \\
\text { Resource }\end{array}$ \\
\hline \multirow{2}{*}{$\begin{array}{l}\text { campus practice } \\
\text { teaching }\end{array}$} & accessibility & $70.5 \%$ & $80.1 \%$ & $83.2 \%$ \\
\cline { 2 - 5 } & importance & $45.4 \%$ & $70.3 \%$ & $75.8 \%$ \\
\hline
\end{tabular}

Several findings could be drawn from TABLE I . Considering for resources obtained, three kinds of social resource obtained from campus practice teaching are intellectual resource (83.2\%), information resource (80.1\%), human resource $(70.5 \%)$ in order. Considering for its impact on employment, the importance of three kinds of social resource obtained from campus practice teaching are listed in the same order: intellectual resource (75.8\%), information resource (70.3\%), human resource (45.4\%). In summary, with the regard of undergraduates employment, intellectual resource and information resource are more important than human resource in campus practice teaching.

\section{B. The Influence of Social Resources Embedded in Social \\ Practice Teaching on Undergraduates Employment}

Social practical teaching includes internship, outside-school practice, and social investigation. Social practical teaching extends education beyond campus. With social network accumulated in such activities, undergraduates can obtain high credibility and matched employment information; job hunters are increased confidence and favorable impression by employers if they can acquire the key recommendation of important members with the characteristics of "weak relationship” in social network.

Similarly, in this part, we asked (1) if graduates obtained three kinds of social resources in social practical teaching and (2) what kinds of social resources played an import role on their employment? Survey results are shown in TABLE II .

TABLE II. THE ACCESSIBILITY AND IMPORTANCE OF SOCIAL RESOURCES IN SOCIAL PRACTICE TEACHING

\begin{tabular}{|l|l|l|c|c|}
\hline \multicolumn{2}{|c|}{ practice teaching pattern } & \multicolumn{3}{c|}{ Social Resource } \\
\cline { 3 - 5 } \multicolumn{2}{|c|}{} & $\begin{array}{c}\text { Human } \\
\text { resource }\end{array}$ & $\begin{array}{l}\text { Information } \\
\text { resource }\end{array}$ & $\begin{array}{l}\text { Intellectual } \\
\text { Resource }\end{array}$ \\
\hline \multirow{2}{*}{$\begin{array}{l}\text { social practice } \\
\text { teaching }\end{array}$} & accessibility & $90.5 \%$ & $82.1 \%$ & $75.4 \%$ \\
\cline { 2 - 5 } & importance & $85.3 \%$ & $70.3 \%$ & $61.8 \%$ \\
\hline
\end{tabular}

Several findings could be drawn from TABLE $\mathbb{I}$. Considering for resources obtained, three kinds of social resource obtained from campus practice teaching are human resource $(90.5 \%)$, information resource $(82.1 \%)$, intellectual resource $(75.4 \%)$ in order. Considering for its impact on employment, the importance of three kinds of social resource obtained from campus practice teaching are listed in the same order: intellectual resource $(85.3 \%)$, information resource (70.3\%), human resource (61.8\%). In summary, with the regard of undergraduates employment, human resource played the most significant role, followed by information resource, and then intellectual resource.

\section{The Influence of Social Resources Embedded in Graduation Thesis Teaching on Undergraduates Employment.}

Graduation thesis is an important part of practice in cultivating the abilities of innovation practical and enterprising spirit of college students. In this process, it is beneficial for students to accumulate human resources to acquire real and accurate materials in a more convenient and efficient way. In the meanwhile, research materials of enterprises can be obtained and combined with students' theoretical level and analysis to enhancing their applied ability by their information resources. The supervisor provides education resource to students when answering students' questions.

Similarly, in this part, we asked (1) if graduates obtained three kinds of social resources in graduation thesis teaching and (2) what kinds of social resources played an import role on their employment? Survey results are shown in TABLE III.

TABLE III. THE ACCESSIBILITY AND IMPORTANCE OF SOCIAL RESOURCES IN GRADUATION THESIS TEACHING

\begin{tabular}{|l|c|l|c|c|}
\hline \multicolumn{2}{|c|}{ practice teaching pattern } & \multicolumn{3}{|c|}{ Social Resource } \\
\cline { 3 - 5 } & $\begin{array}{l}\text { Human } \\
\text { resource }\end{array}$ & $\begin{array}{l}\text { Information } \\
\text { resource }\end{array}$ & $\begin{array}{l}\text { Intellectual } \\
\text { Resource }\end{array}$ \\
\hline \multirow{2}{*}{$\begin{array}{l}\text { graduation thesis } \\
\text { teaching }\end{array}$} & accessibility & $83.2 \%$ & $74.3 \%$ & $68.9 \%$ \\
\cline { 2 - 5 } & importance & $80.1 \%$ & $68.4 \%$ & $58.3 \%$ \\
\hline
\end{tabular}

Several findings could be drawn from TABLE III. Considering for resources obtained, three kinds of social resource obtained from campus practice teaching are human resource $(83.2 \%)$, information resource $(74.3 \%)$, intellectual resource $(68.9 \%)$ in order. Considering for its impact on employment, the importance of three kinds of social resource obtained from campus practice teaching are listed in the same order: intellectual resource $(80.1 \%)$, information resource (68.4.3\%), human resource (58.3\%). In summary, with the regard of undergraduates employment, human resource played the most significant role, while information resource is important as well.

\section{CONCLUSION}

Difficult employment for undergraduates has become a social problem of high concern, which results from the disconnection between classroom teaching and enterprise demand partly. So, domestic universities are trying to strengthen practical teaching to enhance students' practical ability to analyze and solve problems. Based on the perspective of social resource embeddedness, this paper conducts a questionnaire survey on undergraduate students in Wuhan to reveal the deep relationship between practical teaching and undergraduate employment. The results show that in social practice teaching and graduation thesis teaching, human resource with the highest degree of embeddedness, has the greatest impact on undergraduates' employment, while in campus teaching practice teaching, intellectual resource with the highest degree of embeddedness, has the greatest impact on graduates' employment. Therefore, with varying practical teaching patterns, we should attach importance to the 
cultivation and maintenance of core social resources, ultimately to enhance its positive role in undergraduate employment.

\section{ACKNOWLEDGMENT}

Lei ZHOU, Li MA, Rui WANG thank Hubei Provincial Department of Education for Humanities and Social Sciences Research Project (No. 17Q095); 2017 Wuhan Textile University Teaching Research Project.

\section{REFERENCES}

[1] J. S. Coleman, "Social capital in the creation of human capital," American Journal of Sociology, vol. 94, pp. 95-120, 1988.

[2] W. M. Peng, Y. Luo, "Managerial ties and firm performance in a transition economy: the nature of micro-micro link," Academy of management Journal, Vol. 43, pp. 486-501, 2000.

[3] S. H. Park, Y. Luo, "Guanxi and organizational dynamics: Organizational networking in Chinese firms," Strategic Management Journal, Vol. 22, pp. 455-460, May 2001.

[4] B. Bartjargal, M. Liu, "Entrepreneurs assess to private equity in China: the role of social capital," Organization Science, vol. 15, pp. 159-172, 2004.

[5] X. Bian, H. Qiu, "Corporate social capital and its effectiveness," Chinese social science, 2000. (In Chinese)

[6] Q. Zhang, "Social Capital Investment Strategy and Corporate Performance,” Economic Management, 2004. (In Chinese)

[7] C. J. Collins, K. D. CLARK, "Strategic human resource practices, top management team social networks and firm performance: the role of human resource practices in creating organizational competitive advantage,” Academy of Management Journal, vol. 46, pp. 740-751, 2003.

[8] J. Wei, L. Gou, "Research on Cluster Enterprise Growth Based on Dynamic Network Relationship Combination--Taking Zhengtai Group as an Example,” Economic Geography, pp. 787-793, 2009. (In Chinese)
[9] J. Wu, Y. Dai, "Entrepreneur social network, organizational ability and cluster enterprise growth performance," Journal of Management, vol. 10, pp. 516-523, 2013. (In Chinese)

[10] X. Ma, H. He, "The Influence of Network Relationship Embedding on the Performance of SMEs' Technological Innovation-Considering the Mediating Role of Knowledge Acquisition,” Technical Economy, pp. 13-17, 2015. (In Chinese)

[11] B. N. Anand, T. Khanna, "Do firms learn to create value? The case of alliances,” Strategic Management Journal, vol. 21, pp. 295-315, 2000.

[12] D. Lavie, "Alliance portfolios and firm performance: A study of value creation and appropriation in the US software industry," Strategic Management Journal, vol. 28, pp. 1187-1212, 2007.

[13] F. Shen, "A new mode of practical teaching in accounting profession-School-enterprise cooperation,” Foreign investment of China, pp. 63-63, 2013. (In Chinese)

[14] Y. Yuan, "Promoting College Students' Employment with Schoolenterprise Cooperative Education,” Jiangsu Higher Education, pp. 110111, 2011. (In Chinese)

[15] L. Xu, "Research on College Students' Financing Strategy in the Perspective of In formation Asymmetry," Business accounting, pp. 2829, 2015. (In Chinese)

[16] Z. Yu, "Constructing a Practical Teaching System Model for Training Practical Talents," SME management and technology, pp. 147, 2011. (In Chinese)

[17] X. Guo, "Exploration and Reflection on Improving the Employment Ability of Higher Vocational Students under the Employment-oriented 'School-Enterprise Cooperation Order Training' Mode," Jiangxi Chemical Industry, pp. 28-30, 2016. (In Chinese)

[18] P. Zhou, "The Research and Practice about the connection in SchoolEnterprise Cooperation Enterprise Culture," Vocational education, pp. 41-43, 2015. (In Chinese)

[19] H. Ma, "Research on the Problem of Social Resource Allocation in Industrial Clusters in China's High-tech Zones," Jilin University Dissertation,2015. (In Chinese)

[20] J. Nahapiet, S. Ghoshal, "Social capital, intellectual capital and the organizational advantage," Academy of Management Review, vol. 23, pp. 242-266, 1998. (In Chinese) 